\title{
Zwroty ku przestrzeni w badaniach literackich - próba uporządkowania pojęć i podstawowe rozróżnienia
}

\begin{abstract}
Gieba Kamila, Zwroty ku przestrzeni w badaniach literackich - próba uporządkowania pojęć i podstawowe rozróżnienia [Shifts to space in literary research: An attempt at organizing concepts and making basic distinctions]. „Przestrzenie Teorii” 23. Poznań 2015, Adam Mickiewicz University Press, pp. 27-38. ISBN 978-83-232-2920-9. ISSN 1644-6763. DOI 10.14746/ pt.2015.23.2.
\end{abstract}

An increased interest in space in the humanities can be referred to as a spatial, topographic or topological shift. This article is an attempt at organizing these concepts and defining the fundamental differences between them. Based on the findings of European and American researchers (including Edward Soja, Sigrid Weigel, Ernest W.B. Hess-Lüttich, and Joseph Hillis Miller) and a Polish literary scholar (Elizabeth Rybicka), the author tries to distinguish, and define the relationship, between spatial, topographic and topological shifts. This article was inspired by the terminological chaos in the Polish humanities.

„W ostatnich dekadach upowszechnił się zwyczaj opisywania zmian, jakie zachodziły i zachodzą w humanistyce, w kategorii «zwrotu» badawczego"1 - czytamy we wprowadzeniu do tomu zbiorowego Zwroty badawcze $w$ humanistyce. Konteksty poznawcze, kulturowe $i$ społeczno-instytucjonalne. Redaktorzy publikacji stwierdzają, że „Zwrot stał się dziś naczelną kategorią organizującą badania humanistyczne, jak i prowadzoną nad nimi refleksję" 2 . Tę konstatację przywołuję jako punkt wyjścia do próby systematyzacji kierunków badawczych, które są efektem współczesnego wzmożonego zainteresowania kategoriami spacjalnymi w naukach humanistycznych. Podejmuję taką próbę ze względu na to, że mamy obecnie do czynienia nie $\mathrm{z}$ jednym $\mathrm{zw}$ rote $\mathrm{m}$, ale raczej $\mathrm{z}$ kilkoma $\mathrm{zw}$ rot a $\mathrm{mi}^{3}$ badawczymi w kierunku przestrzeni. W refleksji naukowej funkcjonują nazwy: zwrot przestrzenny/spacjalny (spatial turn), topograficzny (topographical turn) oraz topologiczny (topological turn), występujące $\mathrm{w}$ odmiennych kontekstach, ponieważ każde $\mathrm{z}$ tych określeń uruchamia nieco inne perspektywy badawcze i różne sposoby problema-

1 J. Kowalewski, W. Piasek, Wprowadzenie, [w:] „Zwroty” badawcze w humanistyce. Konteksty poznawcze, kulturowe i społeczno-instytucjonalne, red. J. Kowalewski, W. Piasek, Olsztyn 2010, s. 7.

2 Tamże.

3 Te i pozostałe wyróżnienia moje - K.G. 
tyzacji przedmiotu badań. Ów przedmiot jednak pozostaje taki sam we wszystkich trzech orientacjach, a jest nim oczywiście, najogólniej rzecz ujmując, przestrzeń traktowana jako konstrukt kulturowy i społeczny.

Dwa ostatnie $\mathrm{z}$ wymienionych zwrotów znajdują zastosowanie przede wszystkim w literaturoznawstwie, dlatego to właśnie optyka literaturoznawcza i stanowiska badaczy literatury stanowią podstawę niniejszej próby zakreślenia obszarów zainteresowań współczesnych zwrotów ku przestrzeni. Nie oznacza to jednak, że wymienione reorientacje są produktywne tylko w tej dyscyplinie - wręcz przeciwnie, funkcjonują również na gruncie takich nauk, jak m.in. geografia humanistyczna, geografia kulturowa, socjologia, kulturoznawstwo czy antropologia kulturowa. Sprawia to, że humanistyczne zwroty w kierunku przestrzeni stanowią jedną z płaszczyzn transdyscyplinarnego dialogu między wymienionymi obszarami naukowymi.

Czy rzeczywiście granice pomiędzy perspektywą przestrzenną, topograficzną i topologiczną są tak ostre, a istniejące między nimi różnice tak znaczące, że można traktować je jako odrębne zwroty badawcze (zwłaszcza w polskiej humanistyce)? Innymi słowy - czy nie jest to mnożenie bytów ponad potrzebę? Trudno udzielić na to pytanie precyzyjnej, jednoznacznej odpowiedzi, trudno też oczekiwać, że w naukach humanistycznych, które odwołują się do różnych słowników teoretycznych, dojdzie do pełnego uzgodnienia znaczeń decydujących o specyfice spatial, topographical oraz topological turn. Postawione tu pytanie może natomiast stanowić inspirację do próby ich uporządkowania.

Wyjściowe rozróżnienia zostały już w polskich badaniach literackich poczynione, a to za sprawą artykułu Elżbiety Rybickiej Od poetyki przestrzeni do polityki miejsca. Zwrot topograficzny w badaniach literackich, który w 2008 roku ukazał się na łamach „Tekstów Drugich” i którego rozszerzona i uzupełniona wersja weszła w skład tomu zbiorowego Kulturowa teoria literatury. Poetyki, problematyki, interpretacje ${ }^{4}$. To właśnie ten tekst należy uznać za kluczowy dla popularyzacji w rodzimym literaturoznawstwie zwrotów w kierunku przestrzeni, które od dłuższego już czasu funkcjonują w zachodniej refleksji naukowej. Autorka wymienionego artykułu przedstawia najważniejsze kierunki badawcze, jakie wyznaczają zwroty: przestrzenny oraz topograficzny, ponadto już na początku zaznacza, że jej celem nie jest systematyzacja spacjalnych reorientacji:

${ }^{4}$ E. Rybicka, Od poetyki przestrzeni do poetyki miejsca. Zwrot topograficzny $w$ badaniach literackich, „Teksty Drugie” 2008, nr 4; taż, Zwrot topograficzny w badaniach literackich. Od poetyki przestrzeni do polityki miejsca, [w:] Kulturowa teoria literatury. Poetyki, problematyki, interpretacje, t. II, red. R. Nycz, T. Walas, Kraków 2013. 
[...] bardziej niż systematyka, interesować mnie będzie dynamika współczesnych rekonfiguracji przestrzennych, zarówno problemowych, jak i dyscyplinarnych, trajektorie przemieszczeń oraz aktywność rozwojowa tego obszaru zainteresowań. Zwrot przestrzenny/topograficzny bowiem nie tylko bada współczesną przestrzeń w ruchu, ale i sam podlega nieustannie dyslokacjom, ruchom de- i reterytorializacji ${ }^{5}$.

Ruchy de- i reterytorializacji w obrębie przywołanych kategorii badawczych utrudniają ich systematyzację. Dodatkową trudność stanowi chaos terminologiczny - zwrot przestrzenny i topograficzny to nazwy, które często są stosowane wymiennie, bez uwzględnienia szerszego zaplecza teoretycznego. Co więcej, Rybicka, która wprowadziła terminy „zwrot przestrzenny” i „zwrot topograficzny” na grunt polskiej humanistyki, nie rozstrzyga ostatecznie problemu odrębności znaczeń, jakie konotują te zwroty. Z jednej strony podaje argumenty na rzecz ich rozgraniczenia, z drugiej dopuszcza jednak synonimiczne traktowanie spatial i topographical turn, a to ze względu na chiazmatyczny charakter zachodzących między nimi relacji. Badaczka w przywołanych artykułach stosuje m.in. zapis „zwrot przestrzenny/topograficzny”6, sugerujący wymienność czy też równoległość tych dwóch terminów.

Sprawę komplikuje wprowadzenie jeszcze innego pojęcia - mam na myśli termin „geopoetyka”. W pierwszym tomie Kulturowej teorii literatury Rybicka stwierdza: „Przedmiotem geopoetyki, w moim rozumieniu i najogólniej rzecz ujmując, byłyby zatem topografie - zapisy miejsc w tekstach kultury"7. Literaturoznawczyni podobnie (tak samo?) traktuje topographical turn, nawiązując do etymologii wyrażenia topos graphos i stwierdzając, że ów zwrot odnosi się „do domeny graphien, dziedzin przyznających językowemu ujęciu przestrzeni największe znaczenie"8. W takim ujęciu clou zwrotu topograficznego i geopoetyki wydaje się tożsame. Na przykładzie powyższych zarysów definicyjnych geopoetyki i zwrotu topograficznego można pokazać, jak skomplikowany (bo nieokreślony ostatecznie) jest status charakteryzowanych zwrotów, funkcjonujących niekiedy jednocześnie $\mathrm{z}$ innymi, zdawałoby się tożsamymi, koncepcjami badawczymi.

Podejmując próbę określenia różnic istniejących między zwrotem przestrzennym i topograficznym, zacznę od generalnych ustaleń. Ten

5 Taż, Zwrot topograficzny..., s. 313.

6 Tamże, s. 314.

${ }^{7}$ E. Rybicka, Geopoetyka (o mieście, przestrzeni i miejscu we współczesnych teoriach i praktykach kulturowych), [w:] Kulturowa teoria literatury. Gtówne pojęcia i problemy, t. I, red. M.P. Markowski, R. Nycz, Kraków 2012, s. 480. Wyróżnienie jak w oryginale.

8 Taż, Zwrot topograficzny..., s. 314. 
pierwszy funkcjonuje raczej w obszarach anglojęzycznych, podczas gdy ten drugi - w niemieckojęzycznych ${ }^{9}$. Poza odmiennym terytorialnie zasięgiem oddziaływania obu koncepcji, dzieli je również chronologia - nazwa „zwrot przestrzenny” po raz pierwszy została zastosowana w 1989 roku w odniesieniu do geografii humanistycznej przez Edwarda Williama Soję w Postmodern Geographies ${ }^{10}$, natomiast zwrot topograficzny w 2002 roku ogłosiła Sigrid Weigel w artykule Zum „topographical turn”. Kartographie, Topographie und Raumkonzepte in den Kulturwissenschaften ${ }^{11}$. Jednak te okoliczności nie decydują o odrębności zwrotów: przestrzennego i topograficznego. Gdyby podstawą ich systematyzacji uczynić właśnie terytorialny zasięg występowania nazw, wówczas z łatwością można by zakwestionować zasadność traktowania spatial i topographical turn jako oddzielnych reorientacji badawczych i stwierdzić, że są to tylko pojęcia, które po prostu sytuują badania humanistyczne w obrębie pewnych wspólnot interpretacyjnych. Taki zarzut bywa zresztą stawiany kategorii „zwrotu badawczego” w ogóle: „[...] być może kategoria «zwrotu» badawczego jest jedynie współczesnym narzędziem do zakreślania granic własnych, lokalnych wspólnot interpretacyjnych"12 - twierdzą redaktorzy cytowanej we wstępie publikacji. Powody rozdzielenia tych orientacji w humanistycznych eksploracjach przestrzeni muszą sięgać dalej i znajdować uzasadnienie nie tylko $\mathrm{w}$ określanym terytorialnie uzusie interpretacyjnym.

Różnicę między spatial turn i topographical turn wyznacza - zdaniem Rybickiej - relacja nadrzędności i podrzędności. O ile zwrot topograficzny „odnosi się do domeny graphien, dziedzin przyznających językowemu ujęciu przestrzeni największe znaczenie"13, o tyle zwrot przestrzenny to formuła określająca współczesne zainteresowanie przestrzenią w różnych dyscyplinach i dziedzinach naukowych, by wymienić - poza literaturoznawstwem - kulturoznawstwo, antropologię, filozofię, historię sztuki czy geografię humanistyczną. Zgodnie z propozycją Rybickiej zwrot topograficzny stanowi „lokalną czy też pozycyjną odmianę zwrotu przestrzennego"14 - miałby zatem znaczenie węższe, ponieważ dotyczące wyłącznie tych sposobów konceptualizacji przestrzeni, które angażują wspomnianą domenę graphien. Zogniskowanie problematyki

9 Taż, Od poetyki przestrzeni do poetyki miejsca..., s. 22-23.

10 E.W. Soja, Postmodern Geographies, New York 1989.

11 S. Weigel, Zum „topographical turn”. Kartographie, Topographie und Raumkonzepte in den Kulturwissenschaften, „KulturPoetik” 2002, $\mathrm{nr} 2$.

12 J. Kowalewski, W. Piasek, Wprowadzenie, s. 11.

${ }^{13}$ E. Rybicka, Zwrot topograficzny..., s. 314.

14 Tamże. 
przede wszystkim na sposobach i strategiach zapisu, opisu, reprezentacji i tekstualizacji kategorii spacjalnych powoduje, że dla badań literackich bardziej adekwatna jest nazwa „zwrot topograficzny”.

$\mathrm{W}$ gruncie rzeczy uznanie, że zwrot topograficzny funkcjonuje w obrębie zwrotu przestrzennego, a zatem jest podrzędny względem niego, wyklucza uznanie spatial oraz topographical turn za odmienne paradygmaty. Oznaczałoby to, że zwrot przestrzenny jest po prostu inkluzywny względem topograficznego. W celu uznania ich za odmienne paradygmaty, należałoby wykazać, że różnią się proponowanymi instrumentariami badawczymi, a także - co z tym związane - że kierunki badawcze, które wyznaczają, nie nakładają się na siebie. Na takie differentia specifica wskazuje Weigel, która akcentuje różnice teoretyczne i metodologiczne istniejące pomiędzy angloamerykańskimi a europejskimi badaniami kulturowymi nad przestrzenią, określając je wręcz jako „kartograficzny zatarg"15. Niemiecka badacza stwierdza, że zwrot przestrzenny w amerykańskich studiach kulturowych oznacza m.in. przekształcanie „klasycznych" dyskursów w taki sposób, że to właśnie przestrzeń staje się w nich nadrzędną kategorią badawczą. Jako przykład podaje koncepcję orientalizmu Edwarda Saida, która w ramach topographical turn zostaje ukierunkowana na teorię, opierającą się na ogólnym założeniu, że poczucie tożsamości narodowej nie musi być tożsame $\mathrm{z}$ terytorialnymi ramami państwa - teorię uprzywilejowującą przede wszystkim problematykę przemieszczenia, związaną z doświadczeniem migracji, której efektem może być $n p$. wygnanie czy diaspora ${ }^{16}$. W zwrocie przestrzennym dominującym w amerykańskich cultural studies zainteresowanie badawcze jest skierowane w głównej mierze na praktyki wytwarzania przestrzeni kulturowej. Tymczasem centralnym zagadnieniem eksplorowanym w ramach zwrotu topograficznego jest inny problem - ważniejsze od praktyk wytwarzania konstruktów spacjalnych są techniki ich reprezentacji za pośrednictwem symbolicznych (np. literackich) map. Stąd kluczową kategorią topographical turn staje się właśnie mapowanie. W tym miejscu warto zasygnalizować, że podział na odmienne orientacje angloamerykańskie i europejskie (czy, jak pisze Rybicka, anglojęzyczne

15 S. Weigel, On the „Topographical Turn”: Concept of Space in Cultural Studies and Kulturwissenschaften. A Cartigraphic Feud, przeł. M. Kyburz, U. Kornmeier, „European Review" 2009, vol. 17, nr 1.

16, „[...] the topographical turn in Cultural Studies is less about mapping in metaphorical terms than transforming «classic» discourse-historical criticism, like Edward Said's Orientalism (1978), into a prescriptive conception of another, alternative theory, founded upon the experience of cultural identity no longer equalling national territory. Such experience becomes heightened in the figure of displacement, which takes the place of conventional concepts of migration, such as «exile» or «diaspora»". Tamże, s. 191. 
i niemieckojęzyczne) nie może być traktowany jako absolutnie nieprzekraczalny. Kategoria symbolicznego mapowania jest również badana na tym pierwszym gruncie, by przywołać chociażby stanowisko amerykańskiego badacza Josepha Hillisa Millera, który w Topographies stwierdza, że „powieść to symboliczne mapowanie”17 i podaje kilka znaczeń literackiej topografii - jest to narratywna konstrukcja przestrzeni; metafory i toposy przestrzenne; określona organizacja przestrzeni przedstawionej; a także - przede wszystkim - literackie procedury, za pomocą których na przestrzeń, miejsce i krajobraz nanoszone są określone znaczenia pozaprzestrzenne.

Zainteresowanie literacką topografią jest tak dynamiczne, że - zdaniem Weigel - reprezentacje przestrzeni w literaturze nie są już jedynie tekstualizowanymi, symbolicznymi mapami. Spacjalne toposy czy figury narracyjne zaczynają być interpretowane jako konstrukcje, które posiadają swoje „specyficzne, rozpoznawalne geograficznie lokalizacje”18. Ten obszar zwrotu topograficznego w literaturoznawstwie dotyczy szerokiego spektrum zagadnień wykraczających poza sam tekst: począwszy chociażby od relacji pomiędzy pisarzem a miejscem, ujmowanej $\mathrm{w}$ ramy biografii czy autobiografii ${ }^{19}$; poprzez badanie specyfiki środowisk twórczych przez pryzmat ich geograficznego ulokowania; aż po konstruowanie dosłownych map ${ }^{20}$ czy atlasów ${ }^{21}$, wiodących śladami twórców lub miejsc zapisanych $\mathrm{w}$ utworach literackich. W takim ujęciu konsekwencją zwrotu topograficznego byłaby m.in. turystyka literacka. Z tym podejściem polemizuje inny niemiecki badacz, Ernst Hess-Lüttich, zdaniem którego Sigrid Weigel błędnie interpretuje zwrot topograficzny jako impuls do skupienia się na geograficznie ulokowanych, realnych miejscach. Hess-Lüttich nie wiąże z topographical turn praktyk związanych z geografią literacką czy turystyką literacką. Za sedno tego zwrotu uznaje raczej to, na co Weigel

17 J. Hillis Miller, Topographies, Stanford University Press, 1995, s. 19.

18 „As distinct from Cultural Studies, what ensues from the topographical turn in literary theory is that places are no longer viewed merely as narrative figures or topoi, but also as specific, geographically identifiable locations”. S. Weigel, On the „Topographical Turn”..., s. 192. To i pozostałe tłumaczenia moje - K.G.

19 Zob. np. M. Czermińska, Miejsca autobiograficzne. Propozycja $w$ ramach geopoetyki, „Teksty Drugie” 2011, nr 5.

20 Zob. np. projekt „Literacka Małopolska” i utworzona w jego ramach mapa ze szlakami wiodącymi śladami pisarzy i tekstów literackich dotyczących tego regionu: $<\mathrm{http}: / /$ readingmalopolska.pl/pl/mapa,38.htm> [20.02.2014].

${ }^{21}$ Zob. np. Atlas literatury, red. M. Bradbury, przeł. A. Błasiak, D. Gostyńska, M. Jędrzejak, I. Libucha, Warszawa 2002; F. Moretti, Atlas of European novel, 1800-1900, London 1999; Z. Jaskóła, B. Górska, Literacki atlas Polski - przewodnik turystyczny, Kraków 2007. 
wskazuje w pierwszym rzędzie - kulturowe reprezentacje przestrzenności, konstruowane za pomocą narracyjnych, literackich map ${ }^{22}$. Zakreśla zatem dokładniejsze granice zwrotu topograficznego, ograniczając je do kręgu zagadnień związanych wyłącznie z literacką tekstualizacją kategorii spacjalnych.

Reprezentacja topografii w literaturze ma raczej charakter performatywny niż mimetyczny - to bardziej actio niż decsriptio ${ }^{23}$. Mapa literacka nie odzwierciedla rzeczywistości - nie można jej falsyfikować, ponieważ zasadą jej konstruowania jest odmienność względem „neutralnego” krajobrazu $^{24}$. W ten sposób literackie reprezentacje przestrzeni traktuje Hillis Miller, który widzi w nich nie tyle opisywanie, ile działanie: „Topografia miejsca nie jest czymś, co zostało po prostu dane i czeka na opisanie. Jest tworzona performatywnie za pomocą słów lub innych znaków, np. w piosence lub utworze poetyckim"25. Performatywność literackiej topografii oznacza, że narracje spacjalne mogą stanowić narzędzie służące do konstruowania geografii wyobrażonej, która nakłada się na pozaliterackie krajobrazy oraz zmienia ich realną percepcję.

Powróćmy jeszcze do kategorii mapy. Jak już powiedziano, europejskie badania kulturowe bardziej koncentrują się na teoretyzowaniu literackich kartografii (zwrot topograficzny), a mniej na rekonceptualizacji znaczenia przestrzeni (zwrot przestrzenny). Właśnie z tego powodu większy nacisk jest kładziony na słowo „graficzny”, co podkreśla, że konstrukcje przestrzeni stanowią zapisy (tekstowe sygnatury) społecznych praktyk symbolicznych i materialnych ${ }^{26}$. Centralną procedurą badawczą jest $\mathrm{w}$ takiej perspektywie dekodowanie tekstowych znaczników przestrzeni. $\mathrm{W}$ związku z tym kluczowe zagadnienia podejmowane $\mathrm{w}$ ramach topographical turn koncentrują się wokół takich kategorii, jak symboliczne mapowanie, literacka topografia i kartografia ${ }^{27}$. Jednak metafory mapy

22 E.W.B. Hess-Lüttich, Spatial Turn. On the Concept of Space in Cultural Geography and Literary Research, „Meta-Carto-Semiotics. Journal for Theoretical Cartography” 2012, vol. 5 , s. 6.

${ }^{23} \mathrm{O}$ performatywnym charakterze reprezentacji zob. M.P. Markowski, O reprezentacji, [w:] Kulturowa teoria literatury. Główne pojęcia i problemy, red. M.P. Markowski, R. Nycz, Kraków 2012, s. 289-290.

${ }^{24} \mathrm{~W}$ ten sposób Michał Paweł Markowski referuje koncepcję reprezentacji performatywnej według Wolfganga Isera - zob. tamże.

25 „The topography of a place is not something there already, waiting to be described, constatively. It is made, performatively, by word or other signs, for example, by a song or a poem”. J. Hillis Miller, Topographies, s. 276.

26 S. Weigel, On the „Topographical Turn”..., s. 194.

${ }^{27} \mathrm{O}$ kategorii mapy w polskich badaniach literaturoznawczych zob. m.in.: M. Dajnowski, Kilka uwag o domniemanym zwiąku map i pejzażu literackiego, „Białostockie 
i mapowania - by przywołać jeszcze raz Rybicką - mogą okazać się zbyt statyczne dla sygnowania przestrzennych reorientacji i reprezentacji. Literackie mapy nie mogą być dekodowane jako konstrukcje dwuwymiarowe, ponieważ są to raczej trójwymiarowe kartografie migracji i dyslokacji, w których wymiar przestrzenny musi być rozszerzony o wymiar historyczny ${ }^{28}$. Tekstualna mapa jest więc osadzana w szerszej, pozatekstowej perspektywie, w której szczególnie istotne jest zagadnienie tożsamości, związane np. z wytwarzaniem krajobrazów ideologicznych, geografii mitycznej29 czy domen symbolicznych ${ }^{30}$, mających zaświadczać o prawie własności danej grupy do określonego terytorium. Ten krąg problemów uruchamia słowniki badawcze wyprowadzone $\mathrm{z}$ badań postkolonialnych (czy - jak proponuje Hanna Gosk dla sytuacji polskiej postzależnościowych ${ }^{31}$ ), które Weigel wiązała $\mathrm{z}$ badaniami przestrzeni w ramach amerykańskich studiów kulturowych. Do tego samego wniosku prowadzą spostrzeżenia Hillisa Millera o performatywnym znaczeniu literackich topografii - w perspektywie postkolonialnej mapa może być badana jako narzędzie władzy ${ }^{32}$, wytwarzające określoną wizję przestrzeni. Widać więc po raz kolejny, że pola zainteresowań zwrotu przestrzennego i topograficznego nie są dwoma zupełnie odrębnymi zestawami pytań i problemów badawczych, że przenikają się one i krzyżują, że praktyki przestrzenne i reprezentacje przestrzeni $\mathrm{w}$ istocie mają charakter chiazmatyczny.

$\mathrm{Na}$ tym kłopoty z humanistycznymi zwrotami ku przestrzeni się nie kończą. Na gruncie badań niemieckojęzycznych doszło bowiem do kolejnego rozróżnienia - do repertuaru spacjalnych zwrotów dołączył jeszcze jeden - topologiczny. Za punkt wyjścia obieram spostrzeżenie Hess-Lütticha, który - nawiązując do Struktury tekstu artystycznego Jurija Łotmana - uznaje, że synonimiczne traktowanie zwrotu topograficznego i topologicznego jest metodologicznym nieporozumieniem:

[...] te terminy, które odnoszą się do technicznych i kulturowych reprezentacji przestrzennych (np. zwrot topograficzny), nie powinny być mylone z tymi, które

Studia Literaturoznawcze" 2012, nr 3; H. Kubicka, Literatura i mapy. Modele kartograficzne $w$ badaniach nad literatura popularna, [w:] Kody kultury. Interakcja, transformacja, synergia, red. H. Kubicka, O. Taranek, Wrocław 2009; E. Konończuk, Mapa w interdyscyplinarnym dialogu geografii, historii i literatury, „Teksty Drugie” 2011, nr 5; E. Rybicka, Mapy. Od metafory do kartografii krytycznej, „Teksty Drugie” 2013, nr 4.

${ }^{28}$ E. Rybicka, Zwrot topograficzny..., s. 324.

29 Tamże, s. 316.

${ }^{30}$ L.M. Nijakowski, Domeny symboliczne, Warszawa 2006, s. 108.

31 Zob. H. Gosk, Opowieści skolonizowanego/kolonizatora. W kręgu studiów postzależnościowych nad literatura polska XX $i$ XXI wieku, Kraków 2010.

32 Więcej na ten temat zob. E. Konończuk, Mapa... 
dotyczą deskrypcji przestrzeni literackiej i struktur przestrzennych w produktach estetycznych (np. zwrot topologiczny) ${ }^{33}$.

Najprościej mówiąc, zmiana perspektywy z topograficznej na topologiczną oznacza przesunięcie punktu ciężkości z problemu reprezentacji na problem jej systemowej struktury - ze znaczenia na znak, z interpretacji na analizę, z akcji na deskrypcję. Według Hess-Lütticha perspektywa topograficzna uznaje przestrzeń $\mathrm{w}$ tekście literackim za geografię wyobrażoną, której literackie konstruowanie stanowi pewną praktykę społeczną. Kluczowym zadaniem w tak sprofilowanych badaniach byłoby więc wykrycie znaczenia konstrukcji przestrzennych dla dystrybucji wiedzy, władzy czy uprzedzeń ${ }^{34}$. Badacz zbliża tak sprofilowane zagadnienie literaturoznawcze do przedmiotu zainteresowania geografii humanistycznej.

W perspektywie topologicznej natomiast istotniejsze od samego znaczenia są narzędzia jego konstruowania - znaki. Badania zorientowane topologicznie posługują się tradycją semiotyczną i retoryczną do demaskowania struktury relacji przestrzennych. Inaczej rzecz ujmując - przestrzeń jest tu traktowana jako system znaków, generujący znaczenia konstytuujące za pośrednictwem narracji społeczną rzeczywistośćc ${ }^{35}$. Oznacza to, że ta perspektywa skupia się na sposobach kodowania znaczeń w literackich konstrukcjach przestrzeni - jej językowej produkcji. Podczas gdy topografia bada znaczenia reprezentacji przestrzennych, topologia zajmuje się konstrukcją tych reprezentacji; strukturami, za pomocą których są one budowane; metaforycznymi i retorycznymi strategiami wykorzystywania znaków do kodowania znaczeń nie-przestrzennych ${ }^{36}$. Takie ujęcie powoduje, że zwrot topologiczny jest mniej związany z geografią humanistyczną, bardziej natomiast z tradycją literaturoznawczą, głównie strukturalistyczną.

33 „For instance, those terms which especially address the technical and cultural representation schemes of spatiality (e.g. topographical turn), and which are not to be confused with efforts that concentrate on describing literary spaces and spatial structures in aesthetic products (e.g. topological turn)". E.W.B. Hess-Lüttich, Spatial Turn..., s. 1.

34 „The topographical perspective perceives literary space as imaginary geography, which - similar to cultural geography - refers to the constitutive character of social practice and therefore detects the meaning of spatial relations for the distribution of knowledge, power, prejudices etc.". Tamże, s. 7.

35 „The topological perspective, on the other hand, bridges to the semiotic (and even rhetoric) tradition by exposing the structur of «quasi-spatial relations» and their meaning for literaturę and culture. In the other words, by exposing space as a sign system filled with meaning upon which social reality is constituted". Tamże.

36 Tamże. 
Czy perspektywę topologiczną również można uznać za zwrot badawczy, a zwłaszcza - czy można go uznać za zwrot w polskich badaniach literaturoznawczych? O ile pojęcia „zwrot przestrzenny/topograficzny” są coraz częściej stosowane w polskim dyskursie naukowym, o tyle określenia „zwrot topograficzny” raczej się nie używa. Za przykład weźmy informacje $\mathrm{z}$ portali internetowych przykładowych krajowych pracowni uniwersyteckich i projektów badawczych, które przedmiotem swojego zainteresowania czynią kategorie spacjalne w literaturze. Na stronie zespołu badawczego „Geopoetyka”, afiliowanego przy Instytucie Badań Literackich Polskiej Akademii Nauk, czytamy, że zadania grupy badawczej są skierowane na „rozszerzenie i upowszechnienie na gruncie literaturoznawczym sposobów wykorzystania dostępnego instrumentarium, czerpiącego z kategorii topograficznych"37. Topografią, a nie topologią, zajmuje się również Pracownia Badań nad Przestrzeniami Nowoczesności Wydziału Filologicznego Uniwersytetu Gdańskiego ${ }^{38}$. Członkowie jeszcze innego zespołu badawczego, powołanego w ramach projektu „Regionalizm w badaniach literackich. Tradycje i nowe orientacje”, także nie wymieniają topologii, natomiast wśród analizowanych zagadnień wskazują na zwrot topograficzny i związaną z nim geografię kulturową ${ }^{39}$. Należy jednak odnotować, że w polskiej refleksji literaturoznawczej pojawił się projekt „tropów topografii”, której autorką jest Małgorzata Mikołajczak ${ }^{40}$. Badaczka proponuje prześledzenie znaczeń przestrzennych z zastosowaniem kategorii tropów - metafory, metonimii, synekdochy, litoty i hiperboli. Wprawdzie stosuje te kategorie do analizy konkretnego przypadku - regionalnej literatury lubuskiej - to jednak taka procedura może mieć zastosowanie ogólne i być używana również w badaniu relacji przestrzennych, które nie odnoszą się do regionu. Wymienione tropy stanowiłyby w ujęciu topografii tropów (tropotopografii?) szeregi konstytuujące naddane znaczenie figur przestrzennych, np. konstrukcję geografii mitycznej ${ }^{41}$.

Czy rozróżnienie zwrotów: topograficznego i topologicznego - ogólnie rzecz biorąc zasadzający się na strukturalnym rozróżnieniu między znaczeniem i znakiem - jest zbyt drobiazgowe? Czy nie są to dwie strony

37 Zespół „Geopoetyka”, <http://ibl.waw.pl/pl/o-instytucie/pracownie-i-zespoly/zespolgeopoetyka> [21.02.2014].

$38<$ http://www.fil.ug.edu.pl/upload/files/1630/projekt_pracowni2.pdf> [21.02.2014].

$39<\mathrm{http} / / /$ nowyregionalizm.pl/> [21.02.2014].

${ }^{40}$ M. Mikołajczak, Tropy topografii. Zwiazki między regionalizmem $i$ miejscem w twórczości lubuskiej, „Ruch Literacki” 2010, z. 1.

${ }^{41}$ Zob. taż, „Szli na Zachód osadnicy...”. Rola metaforyki przestrzennej $w$ tworzeniu mitologii Ziemi Lubuskiej, [w:] Od poetyki przestrzeni do geopoetyki, red. E. Konończuk, E. Sidoruk, Białystok 2012. 
tego samego zagadnienia? Jurij Łotman, którym inspiruje się Hess-Lüttich, pisze przecież, że „badanie języka jest drogą (i to istotną) do poznania treści tego, co w nim napisano" ${ }^{42}$. Takie stwierdzenie jest dziś wręcz oczywiste. Może więc bardziej uzasadnione będzie uznanie, że reorientacja topograficzna i topologiczna to nie odrębne zwroty, ale raczej dwie perspektywy badania przestrzeni, jedna eksponująca znaczenie literackiej topografii w kontekście kulturowych teorii literatury, druga nakierowana na analizowanie systemu znakowego, za pomocą którego owo znaczenie jest produkowane. Co wiadome, interpretacja znaczenia wymaga analizowania znaków. W efekcie jedna i druga perspektywa są wobec siebie komplementarne. Nadużywanie kategorii zwrotu badawczego może z łatwością doprowadzić do jej dewaluacji. O ile zwroty: przestrzenny i topograficzny nie budzą większych zastrzeżeń, o tyle kwestię określania perspektywy topologicznej mianem jeszcze jednego zwrotu (przynajmniej na gruncie polskiego literaturoznawstwa) uznaję za otwartą - i dlatego wartą dalszej refleksji oraz, być może, polemiki.

\section{BIBLIOGRAFIA}

Atlas literatury, red. M. Bradbury, przeł. A. Błasiak, D. Gostyńska, M. Jędrzejak, I. Libucha, Warszawa 2002.

Czermińska M., Miejsca autobiograficzne. Propozycja $w$ ramach geopoetyki, „Teksty Drugie" 2011, nr 5.

Dajnowski M., Kilka uwag o domniemanym zwiazku map i pejzażu literackiego, „Białostockie Studia Literaturoznawcze" 2012, nr 3.

Gosk H., Opowieści skolonizowanego / kolonizatora. W kręu studiów postzależnościowych nad literatura polska XX $i$ XXI wieku, Kraków 2010.

Hess-Lüttich E.W.B., Spatial Turn. On the Concept of Space in Cultural Geography and Literary Research, „Meta-Carto-Semiotics. Journal for Theoretical Cartography" 2012, vol. 5 .

Hillis Miller J., Topographies, Stanford University Press, 1995.

Jaskóła Z., Górska B., Literacki atlas Polski - przewodnik turystyczny, Kraków 2007.

Konończuk E., Mapa $w$ interdyscyplinarnym dialogu geografii, historii i literatury, „Teksty Drugie” 2011, nr 5.

Kowalewski J., Piasek W., Wprowadzenie, [w:] „Zwroty” badawcze w humanistyce. Konteksty poznawcze, kulturowe i społeczno-instytucjonalne, red. J. Kowalewski, W. Piasek, Olsztyn 2010.

Kubicka H., Literatura $i$ mapy. Modele kartograficzne $w$ badaniach nad literatura popularna, [w:] Kody kultury. Interakcja, transformacja, synergia, red. H. Kubicka, O. Taranek, Wrocław 2009.

42 J. Łotman, Problem znaczenia $w$ tekście artystycznym, [w:] tenże, Struktura tekstu artystycznego, przeł. A. Tanalska, Warszawa 1984, s. 52. 
Łotman J., Problem znaczenia $w$ tekście artystycznym, [w:] J. Łotman, Struktura tekstu artystycznego, przeł. A. Tanalska, Warszawa 1984.

Markowski M.P., O reprezentacji, [w:] Kulturowa teoria literatury. Gtówne pojęcia i problemy, red. M.P. Markowski, R. Nycz, Kraków 2012.

Mikołajczak M., „Szli na Zachód osadnicy...”. Rola metaforyki przestrzennej $w$ tworzeniu mitologii Ziemi Lubuskiej, [w:] Od poetyki przestrzeni do geopoetyki, red. E. Konończuk, E. Sidoruk, Białystok 2012.

Mikołajczak M., Tropy topografii. Związki między regionalizmem i miejscem $w$ twórczości lubuskiej, „Ruch Literacki” 2010, z. 1.

Moretti F., Atlas of European novel, 1800-1900, London 1999.

Nijakowski L.M., Domeny symboliczne, Warszawa 2006.

Rybicka E., Geopoetyka (o mieście, przestrzeni i miejscu we współczesnych teoriach i praktykach kulturowych), [w:] Kulturowa teoria literatury. Główne pojęcia i problemy, t. I, red. M.P. Markowski, R. Nycz, Kraków 2012.

Rybicka E., Mapy. Od metafory do kartografii krytycznej, „Teksty Drugie” 2013, nr 4.

Rybicka E., Od poetyki przestrzeni do poetyki miejsca. Zwrot topograficzny $w$ badaniach literackich, „Teksty Drugie” 2008.

Rybicka E., Zwrot topograficzny $w$ badaniach literackich. Od poetyki przestrzeni do polityki miejsca, [w:] Kulturowa teoria literatury. Poetyki, problematyki, interpretacje, t. II, red. R. Nycz, T. Walas, Kraków 2013.

Soja E.W., Postmodern Geographies, New York 1989.

Weigel S., On the „Topographical Turn”: Concept of Space in Cultural Studies and Kulturwissenschaften. A Cartigraphic Feud, przeł. M. Kyburz, U. Kornmeier, „European Review” 2009, vol. 17, nr 1.

Weigel S., Zum „topographical turn”. Kartographie, Topographie und Raumkonzepte in den Kulturwissenschaften, „KulturPoetik” 2002, nr 2. 